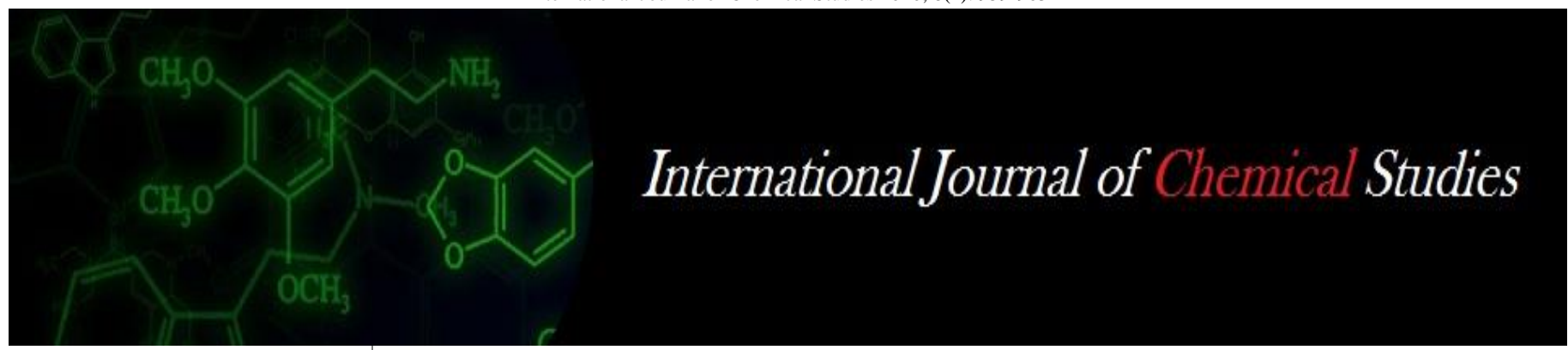

P-ISSN: 2349-8528

E-ISSN: 2321-4902

www.chemijournal.com

IJCS 2020; 8(2): 959-963

(C) 2020 IJCS

Received: 04-01-2020

Accepted: 06-02-2020

Somu G

AICRP on Sorghum, KVK,

Chamarajanagar, Karnataka, India

Nagaraja TE

AICRP on Pigeonpea, GKVK,

University of Agricultural

Sciences, Bengaluru, Karnataka, India
Corresponding Author:

Somu G

AICRP on Sorghum, KVK,

Chamarajanagar, Karnataka,

India

\section{Genetic variability, heritability and genetic advance in first clonal stage of sugarcane}

\author{
Somu G and Nagaraja TE
}

DOI: https://doi.org/10.22271/chemi.2020.v8.i20.8890

\begin{abstract}
Genotypic coefficient of variability gives the magnitude of genetic variance present in the population. The heritability in broad sense is a measure of proportion of total genetic variance reflecting the performance repeatability and its appropriate estimate for clonally propagated crops like sugarcane. The genetic advance as per cent mean summarizes the information contained in the heritability and genotypic coefficient of variability. Hence, the information on these parameters is of paramount importance to sugarcane breeders.
\end{abstract}

Keywords: GCV, PCV, heritability, genetic advance

\section{Introduction}

Among the sugar crops, sugarcane, accounts for over 70 per cent of the world's sugar production (Anon., 2017) ${ }^{[1,2]}$. Sugarcane (Saccharum spp. hybrids) is a genetically complex crop of major economic importance in tropical and subtropical countries. Cane industry require high sugar producing varieties with other desired agronomic traits.

In India, sugarcane is grown under diverse agro-climate situations covering an area of $5.2 \mathrm{~m}$ ha and production of 364.0 million tonnes of sugarcane with productivity of $70.39 \mathrm{t} / \mathrm{ha}$ (Anon., 2017) ${ }^{[1,2]}$. Principal sugarcane growing states are Karnataka, Tamilnadu, Maharashtra, Andhra Pradesh, Uttar Pradesh and Gujarat. In Karnataka sugarcane is grown in an area of 4.30 lakh hectare and production of 45.3 million tonnes of sugarcane with annual productivity of 93.80 t/ha (Anon., 2017) ${ }^{[1,2]}$.

Globally, sugarcane is cultivated over an area of $24.10 \mathrm{~m}$ ha with an annual production of 1329.3 million tonnes and an annual productivity of 75.70 t/ha. In Cauvery Command Area sugarcane is grown in an area of 0.61 lakh hectare with the production of 77.10 lakh tonnes of sugarcane and productivity of $101.80 \mathrm{t} / \mathrm{ha}$ (Anon., 2017) ${ }^{[1,2]}$. In India 24.39 million tonnes of sugar is produced, but the projected requirement of sugar by 2030 is 36 million tonnes which has to be achieved from the existing cane area through improved varieties and management for cane yield and sugar recovery as further expansion in area is not possible.

Understanding of various genetic parameters that govern a population under improvement is essential for proper planning and direction of plant breeding programme. Genetic variability and heritability are useful parameters that can help the breeding during different stages of crop improvement. The success of such programme will largely depend on the extents of genetic variability available in the base population and heritability of the characters under improvement. Therefore, a clear understanding of genetic parameters is of paramount importance to develop a breeding strategy. Genetic variability accumulated and conserved in the form of diverse plant types is immediately valuable for shaping new varieties. This forms the basic genetic wealth on which plant breeders could operate for reconstructing the existing genotypes.

The information on the nature and the magnitude of variability present in the genetic material is of prime importance for a breeder to initiate any effective selection programme. Genotypic and phenotypic coefficients of variation along with heritability as well as genetic advance are very essential to improve any trait because this would help in knowing whether or not the desired objective can be achieved from the material (Tyagi and Singh, 1998) ${ }^{[15]}$. Since, cane yield is a complex trait the association of different traits with it would be an important criterion for the development of high yielding, high sugared and mid-late maturing varieties in sugarcane. 


\section{Material and Methods}

First Clonal Generation $\left(\mathbf{C}_{\mathbf{1}}\right)$ or Settling Nursery

Fifty five genotypes selected from 2308 seedling nursery based on evaluation were planted in eksali 2015. Each genotype was planted in two rows of $6.0 \mathrm{~m}$ length spaced at $90 \mathrm{~cm}$ apart $(2 \mathrm{R} \times 6 \mathrm{~m} \times 0.9 \mathrm{~m})$ with three budded setts per meter in augmented design with five blocks along with three checks viz., CoVC 99463, Co 86032 and Co 62175. All the recommended package of practices were adopted to raise the better crop stand.

\section{Data Recorded in First Clonal Generation $\left(C_{1}\right)$ Crop}

Observations were recorded on the following traits for each genotype before and at the time of harvest in the settling nursery $\left(\mathrm{C}_{1}\right)$ crop.

1. Number of tillers/plot

2. Number of millable canes /plot

3. Millable cane length $(\mathrm{cm})$

4. Cane diameter $(\mathrm{cm})$

5. Number of internodes

6. Internode length $(\mathrm{cm})$

7. Single cane weight $(\mathrm{kg})$

8. Pol per cent juice

9. Brix per cent juice

10. CCS per cent

11. CCS cane yield

12. CCS yield (t/ha)

13. Purity per cent

14. Cane yield (t/ha)

15. HR Brix Yield (t/ha)

\section{Results and discussion}

Improvement of any traits in a crop depends upon the amount of variability present in the base population, in the absence of which there shall be no response to selection. In the present study, the genetic parameters like phenotypic and genotypic coefficients of variation (PCV and GCV), heritability in broad sense $\left(\mathrm{H}_{\mathrm{bs}}\right)$ and genetic advance as per cent mean were estimated to know the nature and magnitude of variation existing among the genotypes under study (Table 1, 2 and Fig $1)$

Genetic variability, heritability and genetic advance for Different Characters in First Clonal Stage

1. Number of tillers/plot.

The GCV and PCV were high $(31.06 \%$ and $31.43 \%$, respectively). The heritability estimate was high $(97.68 \%)$ coupled with high genetic advance as per cent mean $(63.25 \%)$.

\section{Number of Millable Canes per Plot}

The GCV and PCV were high $(33.36 \%$ and $33.72 \%$, respectively). It exhibited high heritability (97.91\%) coupled with high genetic advance as per cent mean of 68.00 per cent.

\section{Millable cane length $(\mathrm{cm})$}

Heritability estimate was high $(96.97 \%)$ coupled with high genetic advance as predicted per cent mean $(21.04 \%)$ with moderate GCV and PCV (10.37\% and 10.53\%).

\section{Cane diameter $(\mathrm{cm})$}

The GCV and PCV were low (7.73\% and 9.50\%). This trait exhibited the high heritability estimate of 66.13 per cent and moderate genetic advance as per cent mean of 12.94 per cent.

\section{Number of internodes}

Moderate GCV (11.66\%), PCV (13.55\%) coupled with high heritability estimate $(74.04 \%)$ and high genetic advance as per cent mean $(20.67 \%)$ were noticed for this character.

\section{Internode length $(\mathrm{cm})$}

The length of the internodes shows Moderate GCV (16.09\%) and PCV (18.75\%) coupled with high heritability estimate $(73.60 \%)$ and high genetic advance as per cent mean $(28.43 \%)$ were noticed for this character.

\section{Single cane weight (kg)}

Single cane weight shows Narrow difference between genotypic $(21.73 \%)$ and phenotypic coefficient of variation $(23.41 \%)$ recorded with high heritability $(86.19 \%)$ coupled with high genetic advance $(41.56 \%)$ as per cent mean.

\section{Pol per cent juice}

Pol per cent is seen that trait exhibited the lower genotypic coefficient of variation of 8.51 per cent and phenotypic coefficient of variation of 8.73 per cent. Heritability estimate was high (95.03 per cent) coupled with moderate genetic advance as predicted per cent mean (17.08\%).

\section{Brix per cent juice}

It is observed that Lower values of GCV (6.53\%) and PCV (6.79\%) coupled with high heritability estimate $(92.44 \%)$ and moderate genetic advance as per cent mean (12.93\%) were noticed for this character.

\section{Commercial cane sugar per cent (CCS\%)}

It shows Lower values of GCV (9.56\%), PCV (9.88\%) and high heritability of 93.62 per cent coupled with moderate GAM (19.05\%) were recorded for this character.

\section{CCS cane yield}

CCS Cane yield showed PCV (24.82\%) coupled with high heritability estimate $(87.48 \%)$ and GAM (44.73\%) was observed.

\section{CCS yield (t/ha)}

CCS yield ( $\mathrm{t} / \mathrm{ha}$ ) is noticed Narrow difference between genotypic and phenotypic coefficient of variation and higher genotypic (49.03\%) and phenotypic (49.70\%) coefficients of variation were recorded. A high heritability estimate of 97.31 per cent with highest genetic advance of 99.63 per cent was also noticed for this trait.

\section{Purity per cent $(\%)$}

It is showed Lowest genotypic (3.26\%) and phenotypic $(3.41 \%)$ coefficients of variation were recorded for this trait; while higher heritability estimate $(91.53 \%)$ coupled with low GAM $(6.42 \%)$ was recorded.

\section{Cane yield ( $t /$ ha)}

Cane yield ( $\mathrm{t} / \mathrm{ha})$ is shows the genotypic and phenotypic coefficient of variation was 49.19 per cent and 49.47 per cent, respectively. A high heritability estimate of 98.86 per cent with high genetic advance of 99.98 per cent was attributed to this character.

\section{HR Brix yield (t/ ha)}

It is observed High GCV (48.92\%) and PCV (49.26\%) coupled with high heritability estimate $(98.65 \%)$ and high 
genetic advance as per cent mean $(99.92 \%)$ were noticed for this character.

The information on the nature and the magnitude of inherent variability present in the genetic material is of prime importance for a breeder to initiate any effective selection program. Coefficients of variation along with heritability as well as genetic advance are very essential to improve any trait of sugarcane because this would help in knowing whether or not the desired objective can be achieved from the material (Sanghera et al., 2014) ${ }^{[13]}$.

The scope for improvement through selection is enhanced by the range of variability in the population. The comparison of results showed higher range of variations for number of tillers/plot, number of millable canes/plot, millable cane length $(\mathrm{cm})$, number of internodes, internode length $(\mathrm{cm})$, single cane weight, CCS per cent, CCS yield (t/ha), CCS cane yield, cane yield (t/ha), HR Brix yield (t/ha) and while narrow range of variations were observed in cane diameter, pol per cent juice, Brix per cent juice and purity per cent. Similar results were noticed by Guruprasad Hiremath (2012) ${ }^{[8]}$, Suresh Jaganur (2014) ${ }^{[14]}$ and kasayya (2016) ${ }^{[10]}$.
Amount of inherent variability as measured by genotypic and phenotypic coefficient of variation, which gives information regarding the relative amount of variation in different characters. Higher magnitude of phenotypic and genotypic coefficient of variation was observed in number of tillers/plot, number of millable canes/plot, single cane weight, CCS cane yield, CCS yield, cane yield (t/ha) and HR Brix yield (t/ha) which suggesting that these characters are under the influence of genetic control (Hapse and Hapse, 1990) ${ }^{[9]}$. Hence these characters can be used for further improvement by simple selection practice. Genotypic coefficient of variation were high for germination per cent, sugar yield, cane yield, number of millable canes and single cane weight as reported by Bakshi Ram (1994) ${ }^{[4]}$.

The narrow difference between phenotypic and genotypic coefficient of variation were observed for all the characters, indicating the less environmental effect on expression of these traits thus exhibited high heritability and genetic advance as per cent mean. Hence these traits can be improved by straight selection. Similar findings were reported by Gosh and Singh (1996) and Bhaskar (2003) ${ }^{[5]}$.

Table 1: Range, Mean, GCV, PCV, Heritability and Genetic Advance as percent of mean for fifteen characters in first clonal stage of sugarcane

\begin{tabular}{|c|c|c|c|c|c|c|c|c|}
\hline \multirow{2}{*}{$\begin{array}{l}\text { Sl. } \\
\text { No. }\end{array}$} & \multirow{2}{*}{ Characters } & \multicolumn{2}{|c|}{ Range } & \multirow{2}{*}{ Mean } & \multirow{2}{*}{$\operatorname{PCV}(\%)$} & \multirow{2}{*}{$\operatorname{GCV}(\%)$} & \multirow{2}{*}{$\mathrm{h}^{2} \mathrm{BS}(\%)$} & \multirow{2}{*}{ GA $(\%)$ of mean } \\
\hline & & Min & Max & & & & & \\
\hline 1. & Tiller Number & 35.00 & 125.00 & 77.36 & 31.43 & 31.06 & 97.68 & 63.25 \\
\hline 2. & NMC & 23.00 & 94.00 & 59.69 & 33.72 & 33.36 & 97.91 & 68.00 \\
\hline 3. & Millable cane length $(\mathrm{cm})$ & 157.00 & 257.00 & 207.49 & 10.53 & 10.37 & 96.97 & 21.04 \\
\hline 4. & Cane diameter $(\mathrm{cm})$ & 2.40 & 3.80 & 3.03 & 9.50 & 7.73 & 66.13 & 12.94 \\
\hline 5. & Number of internodes & 13.70 & 23.70 & 18.24 & 13.55 & 11.66 & 74.04 & 20.67 \\
\hline 6. & Internode length $(\mathrm{cm})$ & 7.70 & 19.00 & 12.33 & 18.75 & 16.09 & 73.60 & 28.43 \\
\hline 7. & Single cane weight $(\mathrm{kg})$ & 0.64 & 2.13 & 1.13 & 23.41 & 21.73 & 86.19 & 41.56 \\
\hline 8. & Pol per cent juice & 14.66 & 21.30 & 17.91 & 8.73 & 8.51 & 95.03 & 17.08 \\
\hline 9. & Brix per cent juice & 16.00 & 22.00 & 19.76 & 6.79 & 6.53 & 92.44 & 12.93 \\
\hline 10. & CCS per cent & 9.68 & 18.15 & 13.33 & 9.88 & 9.56 & 93.62 & 19.05 \\
\hline 11. & CCS cane yield & 0.06 & 0.27 & 0.15 & 24.82 & 23.22 & 87.48 & 44.73 \\
\hline 12. & CCS yield (t/ha) & 2.55 & 16.61 & 8.66 & 49.70 & 49.03 & 97.31 & 99.63 \\
\hline 13. & Purity per cent & 79.90 & 98.67 & 90.80 & 3.41 & 3.26 & 91.53 & 6.42 \\
\hline 14. & Cane yield (t/ha) & 21.52 & 126.22 & 64.43 & 49.47 & 49.19 & 98.86 & 99.98 \\
\hline 15. & HRB Yield (t/ha) & 3.75 & 24.92 & 12.78 & 49.26 & 48.92 & 98.65 & 99.92 \\
\hline
\end{tabular}

Table 2: Magnitude of different variability parameters in respect of 15 characters in first clonal sugarcane genotypes

\begin{tabular}{|c|c|c|c|c|c|}
\hline Sl. No. & Characters & GCV $(\%)$ & PCV $(\%)$ & H (bs) (\%) & GAM (\%) \\
\hline 1 & Tiller Number & High & High & High & High \\
\hline 2 & NMC & High & High & High & High \\
\hline 3 & Millable cane length $(\mathrm{cm})$ & Moderate & Moderate & High & High \\
\hline 4 & Cane diameter (cm) & Low & Low & High & Moderate \\
\hline 5 & Number of internodes & Moderate & Moderate & High & High \\
\hline 6 & Internode length $(\mathrm{cm})$ & Moderate & Moderate & High & High \\
\hline 7 & Single cane weight $(\mathrm{kg})$ & High & High & High & High \\
\hline 8 & Pol per cent juice & Low & Low & High & Moderate \\
\hline 9 & Brix per cent juice & Low & Low & High & Moderate \\
\hline 10 & CCS per cent & Low & Low & High & Moderate \\
\hline 11 & CCS cane yield & High & High & High & High \\
\hline 12 & CCS yield (t/ha) & High & High & High & High \\
\hline 13 & Purity per cent & Low & Low & High & Low \\
\hline 14 & Cane yield $(\mathrm{t} / \mathrm{ha})$ & High & High & High & High \\
\hline 15. & HRB Yield $(\mathrm{t} / \mathrm{ha})$ & High & High & High & High \\
\hline
\end{tabular}




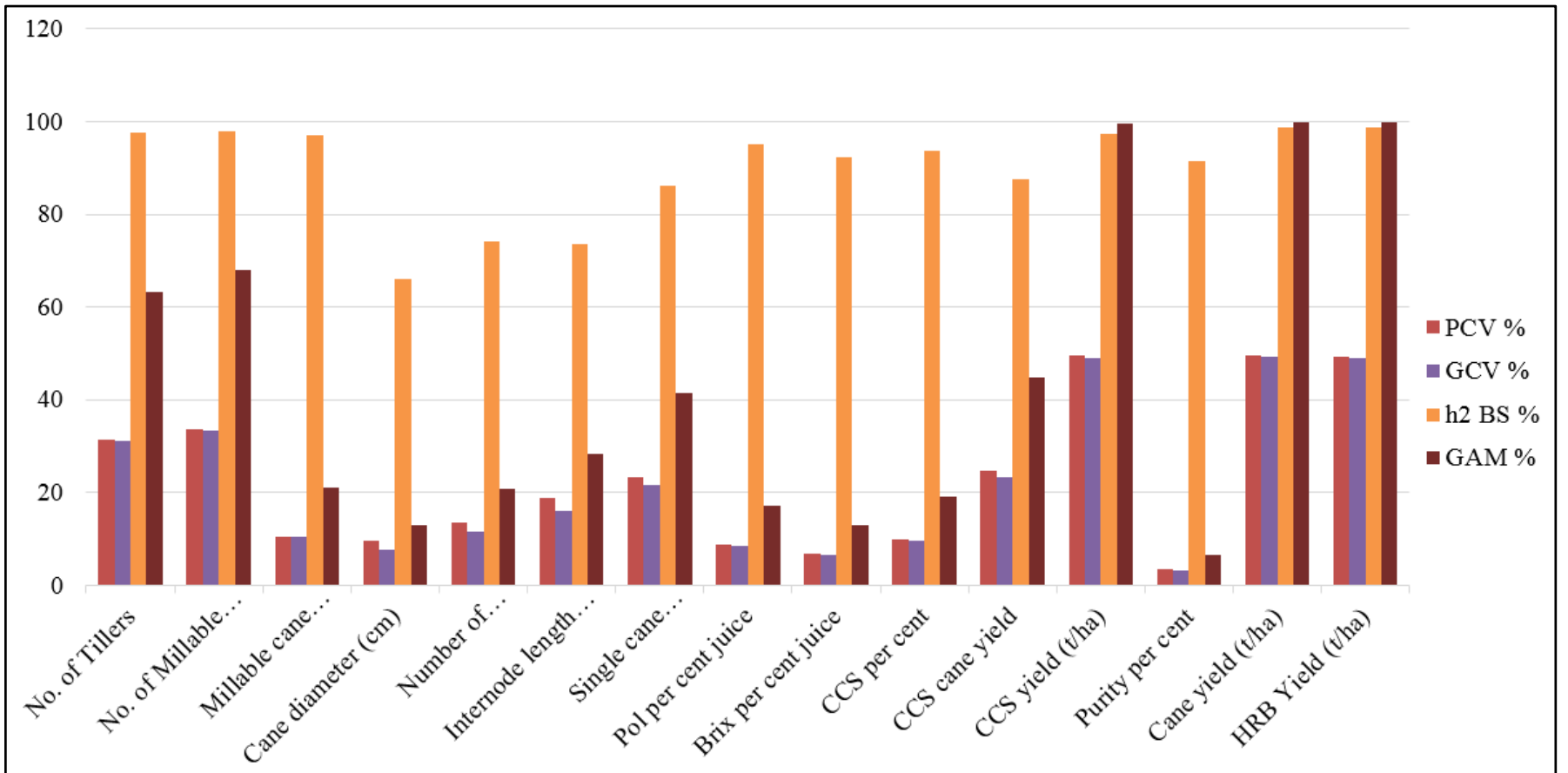

Fig 1: Genetic variability parameters for all characters in first clonal stage of sugarcane genotypes

Cane juice quality is an important aspect in sugarcane. Among the quality characters, pol per cent, Brix per cent and purity per cent exhibited low GCV and PCV, suggesting that limited genetic variability was existence for these traits. These observations were noticed earlier by Gosh and Singh (1996) for juice quality characters.

Among the cane yield components, cane diameter shows low and millable cane length had moderate genotypic and phenotypic coefficient of variation. Gosh and Singh, (1996) reported similar results for mentioned characters. Low variability values recorded in the present study suggested that parental clones used to develop the genotypes under study might possess narrow variability for cane diameter. It is important to note that the phenotypic coefficients of variation were higher than the genotypic coefficients of variation in all the traits, indicating greater influence of environment variations in expression of these traits.

The amount of genetic variation alone may not be of more relevance unless it is supplemented with the information on estimates of heritability of a character which provides a measure of effectiveness of selection for that character as it indicates the heritable portion of the total variation. Since genetic advance is dependent on phenotypic variability and heritability in addition to selection intensity, the heritability estimates coupled with genetic advance values will be more effective and reliable in predicting the response to selection by providing more genetic information on the character. Knowledge on the heritability of characters is important to the breeders, since it suggests that possible improvement can be achieved by simple selection for a particular trait.

High heritability were observed for the all the characters, indicating that selection of clones for these characters will be effective. Bakshi Ram and Hemaprabha (1995) ${ }^{[4]}$ reported that high heritability for number of millable canes, stalk diameter, stalk height, stalk yield, sucrose per cent, purity per cent and sugar yield in the interspecific hybrids of Saccharum species. Similar results were also reported by Patel et al., $(2006)^{[12]}$.

High Genetic advance was observed for number of tillers/plot, number of millable canes/plot, millable cane length $(\mathrm{cm})$, number of internodes, internode length $(\mathrm{cm})$, single cane weight, CCS yield (t/ha), CCS cane yield, cane yield (t/ha), HR Brix yield (t/ha) and it was moderate for Cane diameter, CCS per cent, pol per cent, Brix per cent. Purity per cent had lowest genetic advance as per cent mean. Similar findings were reported earlier by Krishna et al., (2011) ${ }^{[11]}$.

The results of the present study that high heritability and high genetic advance coupled with high GCV and PCV were noticed in number of tillers/plot, number of millable canes/plot, single cane weight, CCS yield (t/ha), CCS cane yield, cane yield (t/ha) and HR Brix yield (t/ha) indicated that these traits were under control of additive gene action, hence phenotypic selection would be effective in improvement of these traits. High heritability and high genetic advance coupled with moderate GCV and PCV were observed for millable cane length $(\mathrm{cm})$, number of internodes, internode length $(\mathrm{cm})$, this results suggesting that there exist a scope to improve cane yield through these traits. Similar results were noticed by Charumathi and Naidu (2015) ${ }^{[6]}$.

CCS per cent, Brix per cent, cane diameter and pol per cent exhibited high heritability with moderate genetic advance and low GCV, PCV indicating simple selection will be effective for improvement of these traits. High heritability coupled with low genetic advance, GCV and PCV was recorded for purity per cent indicating that non-additive type of genes may be governing these characters. Hence selection for these traits will be ineffective. Similar findings were also made by Charumathi and Naidu (2015) ${ }^{[6]}$.

\section{Conclusion}

Wide range of variation was recorded for all the characters studied. Analysis of variance revealed significant mean sum of squares due to blocks and entries for eleven characters viz., tiller number, NMC at harvest, internode length, millable cane, cane stalk diameter, pol per cent, Brix per cent, CCS per cent, purity per cent, HR Brix yield and cane yield. The mean sum of squares due to entries was significant for fourteen characters viz., tiller number, NMC at harvest, internode length, millable cane length, pol per cent, Brix per cent, CCS per cent, purity per cent, HR Brix yield and cane yield, single 
cane weight, number of internodes per cane, CCS cane yield, CCS yield except cane stalk diameter. The mean sum of squares due to checks was significant for number of internodes per cane, internode length, pol per cent, Brix per cent, CCS per cent, CCS yield, HR Brix yield and cane yield. Higher magnitude of phenotypic and genotypic coefficient of variation was observed in number of tillers, number of millable canes, single cane weight, CCS cane yield, CCS yield, cane yield ( $t / h a)$ and HR Brix yield (t/ha). The narrow difference between phenotypic and genotypic coefficient of variation were observed for all the characters, indicating the less environmental effect on expression of these traits thus showed high genetic advance as per cent mean coupled with high heritability.

High heritability in broad sense was observed for all the characters studied. High Genetic advance was observed for tiller number, number of millable cane, millable cane length (cm), number of internodes, internode length $(\mathrm{cm})$, single cane weight, CCS yield (t/ha), CCS cane yield, cane yield (t/ha), HR Brix yield ( $t / h a)$ and it was moderate for Cane diameter, CCS per cent, pol per cent, Brix per cent. Purity per cent had lowest genetic advance as per cent mean.

High heritability and genetic advance coupled with high GCV and PCV were noticed in number of tillers, number of millable cane, single cane weight, CCS yield (t/ha), CCS cane yield, cane yield ( $\mathrm{t} / \mathrm{ha}$ ) and HR Brix yield ( $\mathrm{t} / \mathrm{ha}$ ) indicated that these traits were under control of additive gene action, hence phenotypic selection would be effective in improvement of these traits. High genetic advance and heritability coupled with moderate GCV and PCV were observed for millable cane length $(\mathrm{cm})$, number of internodes, internode length $(\mathrm{cm})$, this results suggesting that there exist a scope to improve cane yield through these traits.

\section{References}

1. Anonymous, 2017, http//www. faostat. com

2. Anonymous, 2017, http//www. indiastat. com

3. Bakshi Ram, Hemaprabha G. Interspecific hybridization of Saccharum species and its consequences on yield and quality. In Genetic Research and Education: Current Trends and the next fifty- year (Eds. Sharma et al.). Indian J Genet. New Delhi. 1995, 1082-1086.

4. Bakshi Ram. Variability, heritability, genetic advance and character interrelationship in sugarcane under coastal conditions of Andhra Pradesh. Indian Agric. Sci. Dig. 1994; 14(1):44-48.

5. Bhaskar JV. Genetic architecture of cane yield, jaggery yield and quality parameters in selected elite clones of sugarcane (Saccharum officinarim L.), M.Sc. (Agri). Thesis, Univ. Agric. Sci. Bangalore, 2003, 114 pp.

6. Charumathi M, Naidu NV. Sequential selection indices for improvement of cane and sugar yields in seedling and succeeding clonal stages of selection in sugarcane. International. J curr. Agric. Res. 2015; 13(3):173-176.

7. Ghosh J, Singh JRP. Non- additive approach for measurement of genotype-environment interaction for cane productivity. Indian Sugar. 1996; 45:773-776.

8. Guruprasad Hiremath. Morphological traits and DNA markers assay based diversity in selected clones of sugarcane. M.sc. (Agri). Thesis, Univ. Agric. Sci., Bangalore, 2012, 197.

9. Hapse RS, Hapse DG. Genetic variability studies in late maturing sugarcane varieties. Bharathiya Sugar. 1990; 15:13-16.
10. Kasayya. Genetic investigation in mid-late maturing sugarcane (Saccharum officinarum) clones isolated for cauvery command area, M. Sc(Agri). Thesis, Univ. Agric. Sci., Bangalore, 2016, 107.

11. Krishna US, Hemanth Kumar M, Mohan Reddy D, Naga Madhuri KV. Study on genetic variability, heritability and genetic advance in plant and ratoon crops of Sugarcane. Geobios. 2011; 38(4):221-224.

12. Patel KC, Patel AI, Mali SC, Patel DU, Vashi RD. Variability, correlation and path coefficient analysis in sugarcane (Saccharum spp). Crop Res. 2006; 32(2):213218.

13. Sanghera GS, Tyagi V, Kumar R, Thind KS. Genetic variability for cane yield, earliness and quality traits in sugarcane under subtropical region of India. International. J Curr. Res. 2014; 6(08):7763-7765.

14. Suresh Jaganur. Evaluation of elite clones of sugarcane (Saccharum officinarum) for cane yield, quality traits and rationing ability. M. Sc(Agri). Thesis, Univ. Agric. Sci., Bangalore. 2014, pp 85.

15. Tyagi SD, Singh DN. Studies on genetic variability for stalk characters in sugarcane. Indian Sugar. 1998; 40(8):259-262. 